\title{
Loomtegelaste kujutamine laulumängudes ${ }^{1}$
}

\author{
Ruth Mirov \\ folklorist \\ ruthmirov@hot.ee
}

\begin{abstract}
Teesid: Artiklis võrreldakse kolme ajaliselt järgneva laulumängukihistuse loomtegelastega mänge nende kujutamislaadi ja mänguvõtete seisukohast. Need on regivärsilise lauluga draamalaadsed mängud, siirdevormilise lauluga tantsulisfiguraalsed mängud ja lõppriimilise lauluga ringmängud.

Vanimate mängude loomtegelane on enamasti antropomorfiseeritud, valdab inimkõnet ja inimtegevusi. Antropomorfiseerimata loomtegelasi kujutatakse aga looduslikest eeskujudest lähtuvalt, iseloomuliku häälitsemise ja liikumise abil. Konflikt mängus lähtub samuti tegelaste loomaomadustest.

Järgmise kihistuse mängudes on loomade kujutamine abstraktsem, looduslähedase jäljendamise asemele tulevad kokkuleppelised tingmärgid ja tantsuline liikumine. Konflikt tuleneb inimestele omastest eetilis-sotsiaalsetest probleemidest.

Viimases, ringmängude kihistuses, esineb veel vähest tingmärkide abil imiteerimist, kuid põhitegevuseks kujuneb (paaris)tants laulu saatel.

Laulumängude ajalises arengus liigutakse reaalset olukorda jäljendavate stseenide etendamiselt abstraktsemate, tantsuliste võtete suunas.

Tõenäoliselt kajastavad muutused loomade-lindude kujutamisel laulumängudes ka üldisi muutusi inimeste loodustunnetuses, kaugenemist loodusest.
\end{abstract}

Märksõnad: etendusmängud, folkloor, laulumängud, loomtegelased, paaristants, ringmängud, sõõrmängud, tantsulis-figuraalsed mängud, voormängud

\section{Sissejuhatuseks}

Laulumängude tähtsusest meie endisaegses eluolus on küllaltki teateid nii teaduslikus kui ka memuaar- ja ilukirjanduses. Ennekõike aga kajastab seda laulumängude suur hulk rahvaluulekogudes ning selle rahvaluuleliigi tüübi- ja variandirikkus. Peamiselt küll noorte harrastus, on laulumängud olnud meelelahutuseks ka lastele ja vanematele inimestele. Sellise universaalsuse lõbustusvormina on neile taganud mitmekülgsus, koosnemine paljudest eri komponentidest: laul sõnalis-muusikalise osana, tantsuline liikumine, draamaelemendid ja sportlik tegevus. Siin sai igaüks oma oskusi, võimeid ja loomingulist fantaasiat rakendada. Sajandite jooksul on laulumängud kui rahvaluuleliik muutunud koos teiste kultuurinähtustega ja üldise elukäsitusega. Nii on vanad, regivärsilise laulu ja dramaatilise tegevusega mängud läbi mitme vaheastme 
möödunud sajandi keskpaiku asendunud riimilise laulu saatel mängitavate ringmängudega, mille põhitegevuseks on paaristants.

Kui rääkida rahvaluule ürgsest sünkretismist, mida vene kirjandusteadlane Aleksandr Vesselovski on defineerinud kui "rütmiliste, tantsuliste liikumiste ühendamist laulu ja muusikaga ning sõna elementidega" (Vesselovski 1940: 200), siis kahtlemata on laulumängud neid rahvaloomingu liike, milles sünkretism eredamalt väljendub. Sünkretismiprobleeme on käsitlenud Ülo Tedre, kes toob esile rahvaluule sünkretismi ja polüfunktsionaalsuse seose: "Rahvaluule sünkretism ei alga kunstiharude kooseksisteerimisest. Sellega kaasneb - võibolla sellele isegi eelneb - kunstiloomingu eesmärkide, funktsioonide eristamatus, n.ö polüfunktsionaalsus" (Tedre 1983: 339). Edasi, viidates filosoof Lucien Lévy- Bruhl'ile, ütleb Ü. Tedre järgmist: "Ometi on vist õigem öelda, et religioon oli algselt teistest ühiskondliku teadvuse vormidest eristamata. Ka inimese peas valitses omasugune sünkretism - ühiseks kompleksiks olid põimunud töökogemused, olmetavad, maagilis-usundilised kujutelmad” (Tedre 1983: 339). Sellist polüfunktsionaalset kompleksi esindavad ka laulumängud. Laias laastus võib meieni jõudnud vanemaidki mängutüüpe pidada lõbustuslikeks, kuid seos tähtpäevakombestikuga viitab nende varasematele usundilis-maagilistele taotlustele. Lõbustuslikust ja rituaalsest funktsioonist vanades mängudes räägib juba soome mängu-uurija Elsa Enäjärvi-Haavio (1936: 103-104). Suured mängupeod nii meil kui soomlastel olid talviste pühade ajal (kõige üldisemalt jõulu teisest pühast kolmekuningapäevani) ning liitusid selle perioodi viljakusrituaalide koosseisu (vt nt Ariste 1927: 121-133; Häyhä 1982: 69-140; Põldmäe 1938: 142-143; Raussi 1966: 208-209; Ruuttu 1926: 86-91; Tampere 1958: 8-12; Vilberg 1920: 80-96, 152-161). Samuti mängiti palju jaanitule juures (mäletatavasti mängitakse ka August Kitzbergi "Libahundi” pöördelise tähtsusega jaaniõhtustseenis "Nukumängu"). E. Enäjärvi-Haavio püüab selgitada "Nukumängu" tagamaid ja osutab võimalikele seostele teiste rahvaste jaanipäeva-pidustustega (Enäjärvi-Haavio 1928: 259-263). Kuna mängimine koondus pööripäevadele, on mõnes laulumängutüübis, kus on tegu suremise ja taasärkamisega või kadumise ja otsimisega (nt "Leinamäng", "Hobusemäng") nähtud talve ja suve, looduse surma ja ärkamisega seotud rituaalide jälgi. Matti Kuusi kõrvutab ka arktiliste kultuuride karupeiesid kujutlusega surevast ja taasärkavast jumalusest (Kuusi 1963: 44). Loomulikult olid karupeiedki mitmekihilised ja polüfunktsionaalsed, neis seguneb jooni esivanematekultusest ja tootemlooma lepitustseremooniast küttrahvastele nii olulise suure jahilooma pidulik-rituaalse tagasisaatmisega jahiloomade ridadesse. Kõige selle juures ei puudu ka vaatemängulis-lõbustuslikud jooned - kuni kaksteist päeva kestnud pidustuste käigus etendati karu auks mitukümmend näidendit. Anton Jürgenstein, toetudes Artturi Kannisto teosele "Über die wogulische Schauspiel- 
kunst", osutab karupeiedel etendatavate pisidraamade ja meie laulumängude mõnedele sarnasusjoontele: improviseerimine etteantud teemal teatud kindlaid pidepunkte silmas pidades, olustikuliste stseenide etendamine farsilikus laadis jms (Jürgenstein 1909: 417-428, 461-465). Rituaalsetes mängudes (ja loomulikult siis üldse draamaelementidega mängudes) nähaksegi teatri eelkäijat. Meil on pulmatseremoonia ja mitmesuguste tähtpäevakommete kõrval just vanad laulumängud kõige lähemal näitemängule. Seda enam, et suurematel pidustustel nagu jõulumängudel oli alati ka pealtvaatajaid, s.o publik.

Hiljem, lõbustusliku funktsiooni esiplaanile tõustes, mängiti laulumänge igasugustel puhkudel, kui aga sobiv seltskond kokku kogunes. Ringmängudel oli üsna hiljuti veel oma osa külanoorte tantsupidudel. Ja lõppude lõpuks on laulumängud ringmängude näol tänapäevalgi mingil määral hingitsev varasema rahvaloomingu liik, kuigi nüüd juba tantsu poolt üsna kõrvale tõrjutud.

\section{Loomtegelased regivärsilise lauluga mängudes}

Kuna vanades regivärsilise lauluga mängudes kujutati stseene talupoja igapäevasest elust, on üsna mitmes neist tegelasteks ka loomad (või linnud; artiklis üldistatult: loomtegelased). Konflikt põhineb sel puhul enamasti vastandusel kodu ja mets, opositsioonilisteks tegelasteks on näiteks karjane ja hunt, kukk ja kull. Teistes mängudes on tegu jälle kadunud loomade otsimisega. Kuna neis puudub peategelasele oma taotlustes otseselt vastandatud tegelane, on konflikt nõrgem, aga mängu pingestavad kadunud looma kättesaamisel ettekerkivad takistused. Üldjoontes jagunevad vanemad laulumängud kindla kujundiga voor- ja sõõrmängudeks ning vabavormilisteks etendusmängudeks. Ülekaalukalt on draamaelemente etendusmängudes, teistes seab kujund (s.o mängijate enamiku paiknemine kas vooris või sõõris) omad piirid tegevusele: dramaatilist tegevust on vähem, aga lisandub tantsuelemente ja eriti lõpplahenduses spordielemente. Loomtegelasi esineb mõlemas mängurühmas. Laul on vanemates mängudes enamasti sissejuhatuseks (ekspositsioonlaul), põhitegevus järgneb laulule (Mirov 1974: 179-186).

Üks populaarseid etendusmänge on "Lambamäng" (Mirov 1976: 29-42, 165177), kus peategelasteks on karjane ja hunt. Karjane koos koeraga käib ümber lammaste, toksib kepiga vastu maad ning laulab aiategemisest ja muust, mis annab ülevaate mängutegevusele eelnenud olukorrast. Laulutekstist selgub ka, kes on tegelased. Tuleb sõnumitoojana esinev hunt, lähetab karjase mingi ettekäändega koju ning varastab lamba (või mitu), kuigi koer püüab teda takistada. Seda korratakse kas sama või erinevate ettekäänetega kuni kõik lambad on ära viidud. Nüüd alles märkab karjane lammaste kadumist, hakkab 
neid otsima ning toasolijaid küsitledes jõuab lõpuks hundi juurde. Puhkeb äge vaidlus, hunt püüab ennast välja valetada, kuid lõpuks peab alla andma ning lubama karjasel lambaid kutsuda. Lambad jooksevadki karjase juurde, mõned lonkavad, on ilmselt vigastatud. Järgnevalt toimub lammaste tervisliku seisundi kindlaksmääramine (neid lastakse üle kepi hüpata) ning süüdlase hundi karistamine või karjase ja hundi kauplemine lammaste jagamiseks. Selline mäng on jaotatav stseenidesse ning kompositsioonilt isegi võrreldav klassikalise draama 5-osalise süžee-ehitusega. Samal ajal on aga "Lambamäng" siiski rahvaluuleteosele omaselt avatud. Tegevuse põhiskeem, samuti terve hulk repliike on küll ette antud, aga alati jääb võimalus vabaks improvisatsiooniks, mis võib minna tervete stseenide juurdemängimiseni. Avatud on mäng ka selle poolest, et on võimalik pealtvaatajaid kaasa tõmmata (nii küsitleb karjane juhuslikke juuresviibijaid lammaste otsimisel jms). Kas improviseeritakse vähem või rohkem, sõltub peategelastest, nende fantaasiast ja huumorimeelest. Võib öelda, et tegelikkuses sünnib mäng uuesti igal mängukorral.

"Lambamängu" süžeeosadel on omad iseloomulikud kujunduslikud komponendid ja väljendusvahendid. Nii kujundab ekspositsioonilise osa karjase laul ja imiteeriv tegevus (s.o aiategemine, mille kujutamiseks on teatud tinglikud võtted - ringi ümber lammaste käimine, kepiga vastu maad toksimine ja lisaks loitsulaadsed sõnad). Järgmistes osades (dispositsioon, kulminatsioon, peripeetia) on põhiline dialoog ja dramaatiline tegevus, millele lõpplahenduses liitub veel sportlik tegevus (üle kepi hüppamine, jooksmine ja tagaajamine). Arusaadavalt on igasuguse mängulise, dramaatilise kujutamise aluseks imitatsioon (Aristotelese järgi on jäljendamine kõikide kunstide läte), siinses käsitluses on aga kahe, oma ülesannetes mõneti erineva kujutamislaadi tähistamiseks kasutatud terminitena väljendeid dramaatiline tegevus (s.t sündmustiku etendamine; see on otseselt tingitud süžeest ja arendab intriigi) ning imiteeriv tegevus (enamasti üksikud jäljendamisvõtted mingi tekstiosa illustreerimiseks, mis tulenevad küll süžeest, pole aga intriigi arendamiseks tingimata vajalikud).

"Lambamängu" peategelane on inimene, kuid talle vastandatud, nn opositsiooniline peategelane on loom - hunt. Loompeategelane on antropomorfiseeritud, nagu neid leidub ennekõike muinasjuttudes. Talle on omane inimmõtlemist väljendav inimkõne ja mitmesugused inimtegevused. Tõuke konfliktiks annab aga tema loomaolemusele iseloomulik joon - kiskjainstinkt, hundilik himu lammaste järele. Kuid varastatud lammaste kohtlemine on jälle "inimlik": ta ajab nad oma karja, teeb neile heina, ei murra ega õgi neid niisama, vaid keedab lambalihast suppi jne. Ka välises kujunduses enamasti ei taotletud loomapärasust. Tegelaste kostümeerimist selle sõna täies tähenduses laulumängudes polnud, enamasti käis mäng ilma igasuguse maskeeringuta. Üksikuid kostümeerimisvõtteid on haruharva siiski kasutatud nagu pahupidi selgaaetud kasukas või 
saba tähistamiseks õletuust vöö vahel (ka üks mängulisi tingmärke). Püüe välimust kuidagi loomapäraseks kujundada on üleskirjutuste põhjal erandlik. Selles mõttes erineb loomade kujutamine jõulustes laulumängudes täielikult samuti talviste pühade kombestikku kuulunud küla mööda õnne soovimas ja lapsi hirmutamas käinud loomakujudest nagu sokk, karu, hobune, hani ja kurg. Kuigi mõlemal puhul on etenduslikud jooned ilmsed, on erineva funktsiooni ja algupäraga nähtuste puhul ka kujutamisvõtted erinevad. Siiski on olemas liikidevahelised stereotüüpsed võtted nagu pahupidi kasukasse riietumine (nt ka mardisandid). Niisiis oli laulumängude butafoorne külg välja arendamata, kuid soovi korral võidi üksikuid rekvisiite või tegelasi identifitseerida aitavaid rõivastusdetaile appi võtta. Põhiliselt loodi kogu olustikukujutus sõnalis-miimiliselt. Vene folklorist Pjotr Bogatõrjov märgib, et dekoratsioonide loomine teatraalsete liigutustega on omane ka väljakujunenud rahvateatrile (Bogatõrjov 1970: 53-64).

"Lambamängu" loompeategelane on küll inimesestatud, aga kõrvaltegelaste juures tuuakse rohkem esile nende loomapäraseid jooni. Kõigepealt väljendub see iseloomulike häälitsuste matkimises - koerad hauguvad, lambad määgivad. Selline jäljendamine on oma olemuselt üdini lastepärane: rääkima hakkav laps nimetabki loomi nende häälitsemise järgi. Loomuliku selekteerimisvõimega on tabatud kõige tüüpilisem detail, mis teatud liigi kindlalt eristab teistest. Ka liikumises ja käitumises püüavad rollikehastajad esile tuua vastavale loomaliigile omast: lambad hoiduvad ühte, jooksevad rabinal, koer kaitseb karja, ajab jälgi jne. Mängu sisestruktuurist lähtudes võib loomast kõrvaltegelaste juures siiski eraldada kahte astet, mis väljendub ka kujutamisvõttestikus. Näiteks ei astu koer tavaliselt üle oma koerafunktsioonide, ainult üksikute teisendite põhjal on tal mõni repliik. Enamasti on ta karjase truu ja arusaaja kaaslane, nimelt on suur jagu karjase teksti suunatud temale. Nii on koeralgi antropomorfseid jooni, aga tunduvalt vähem kui hundil. Lambad on küll konflikti põhjuseks ning ilma nendeta ei saakski mäng toimuda (ilma koerarollita on see võimalik), kuid mängus osalevad nad passiivselt - neid karjatatakse, neid aetakse ära. Mänguintriigi juhivad karjane ja hunt. Mängu esimeses pooles on aktiivsem hunt - tema tegevus viib konfliktini, teises pooles on aktiivsem karjane - tema tegevus viib lõpplahendusele. Eelöeldut arvestades langeb loomtegelaste aktiivsus mänguintriigi juhtimisel kokku nende antropomorfsuse astmega: kõige aktiivsem on hunt ja temal on kõige rohkem inimjooni, siis väheminimestatud koer. Üsna passiivsed on lambad, ja nende kujutamisel tuuaksegi esile ainult loomapäraseid jooni. Hundi antropomorfiseerimise üks põhjusi näib olevat inimtegelasele väärilise vastasmängija andmine. Draamakunsti reeglite põhjal võibki ainult võrdsete vastaste võitlus kulgeda pingeliselt, ning ilmselt on selline joon teadvustamatult olemas ka etendusmängudes. 
Loomtegelastega voormängudest on üldtuntud "Kullimäng". Siin on mõlemad peategelased - kukk ja kull - loomariigist. Nende võitlus käib kanade pärast. Konflikt on niisiis looduslikult paratamatu, siingi vastandub kodu ja mets. Üldisest looduslikust konfliktist lähtub konkreetne - tüli selle kulli ja selle kanakarja vahel, mida lahendatakse jälle inimpäraselt. Linnud on antropomorfiseeritud. Kuigi lähtutakse kahe linnuliigi looduslikust vastuolust, kus röövlind tähendab kodulinnule pidevat ohtu, on olukord mängus teatud määral pea peale pööratud. Siin on algul aktiivsem kanakari oma juhi kukega. Nad õrritavad ja narrivad kulli, kes on tulnud talumaile ilmse sooviga kanu varastada. Juba ekspositsioonlaul sisaldab narrivat motiivi. Ühtlasi selgub laulutekstist, keda mängijad üldse kujutavad. Laulule järgnevas proosadialoogis kemplevadki kukk ja kull niikaua, kuni vihale aetud ja oma taotlustes paljastatud kull vooris viimasena seisvale kanale kallale sööstab, kukk aga koos enda järel lookleva kanakarjaga püüab kulli takistada. Nii on lõpplahenduses aktiivsus kulli poolel, kukk on surutud kaitsjapositsioonile, ning sellega looduslik vahekord taastatud.

Tuleb märkida, et nii "Kullimängu" kui ka eespool käsitletud "Lambamängu" on reeglina mängitud jõulude ajal. Tõenäoliselt oma sobiva vormi tõttu, kuna polnud vaja suurt jooksuruumi, aga ilmselt on siin ka maagiliste taotluste jälgi.

"Kullimäng" on 3-osaline nagu teisedki ekspositsioonlauluga voormängud. Kõik osad on selgelt piiritletavad, kuna neid kujundavad eriliigilised väljendusvahendid: I osa - laul koos väheste tantsuelementidega ja imiteeriva tegevusega, II osa - proosadialoog koos vähese dramaatilise tegevusega ja III osa - sportlik tegevus, mis siin tõesti nõuab jõudu ja osavust ning omab sellisena mängu ülesehituses suhteliselt iseseisvat tähendust. Mänguintriigi aluseks olev tegelaste vastuseade kajastub välises ülesehituseski: opositsiooniline tegelane on ainsana voorist vaba, teised on kogu mängu kestel mingi kinnisvõttega (kas üksteise õlgadest, pihast või riietest kinni hoides) voori seotud, ning peavad nii püsima lõpuni. See piirabki dramaatilise tegevuse hulka.

Esimeses osas, s.o laulu ajal, võiks mängijate voori pidada koguni kooriks ja tantsurühmaks, kusjuures eeslauljaks ja liikumise juhiks on voori esimene (kukk). Voor liigub ümber maaskükitaja (kulli) kas kõnni- või lihtsate tantsusammudega, kuid see liikumine ei jäljenda kuidagi kanade liikumist. Ometi on olemas vanu, maagilise tagapõhjaga imitatsioontantse, mis just matkivad loomade-lindude liikumist. Veelkordne tõend sellest, et eriliigiliste, kuigi mõneski mõttes lähedaste nähtuste väljendusvahendid ja kujutamisvõtted on siiski küllalt erinevad. Et tegelased on linnud, saame "Kullimängus" teada ainult sõna vahendusel - algul laulu, pärast dialoogi kaudu. Teist, s.o dramaatilist põhiosa, kannabki peategelaste dialoog. Niisiis on peategelased täiesti antropomorfsed: valdavad inimkõnet, tegutsevad inimestena (kull kaevab süteauku, 
et veepada keema panna ja kana-kuke sulgi katkuda jms). Ülejäänud on selles mängujärgus nagu pealtvaatajad, publik, ning neid ei püütagi kuidagi kujutada või kehastada, ei inimese- ega linnupärastena. Etendusliku kujutamise seisukohast võiks neid nimetada neutraalseteks tegelasteks. Mängu kolmas osa on üldine füüsiline rabelemine ühe organiseeriva reegliga - voor ei tohi laguneda. Samal ajal kujutab see rabelemine vastaste dramaatilist võitlust, kana kaitsmist kulli eest. Kahtlemata on "Kullimängki" pisidraama - tema sündmustikku etendatakse, kuid kujutamislaad on teistsugune kui etendusmängudes. See on tinglikum, abstraktsem, kuna tantsu- ja spordielementide osatähtsus on suurem. Just voormängudes ilmneb teatud kahepalgelisus - nad on korraga nagu näidendid ja laulusaatega liikumismängud.

Vanadest sõõrmängudest ülemaaliselt tuntumaid on "Hobusemäng", mis samuti kuulus jõulumängude repertuaari. Mängijad käivad sõõris ja laulavad, üks-kaks on sees hobuseks, väljaspool sõõri on samuti üks-kaks hobuseotsijat. Kui laul lõpeb, mängijad seisatuvad ja kinnitavad kätehoidu, moodustades niimoodi tugeva "aia", millest hobune peab välja pääsema. Hobuseks on noormees ning tal peab olema jõudu ja osavust, et välja saada, kuigi hobuseotsijad püüavad teda aidata. Nii toimub siingi üldine rabelemine, mille juures tuleb arvestada järgmist piirangut: hobune võib välja saada kas aiaaugust (käte lahtitrügimisega) või üle aia (tugevad ja osavad poisid on isegi partest kinni karanud ja nii üle tüdrukute peade välja hüpanud), käte alt pugemine on keelatud - ja roomavat hobust ongi raske ette kujutada. Nii ilmneb selles mängus loomapärasuse taotlemine sellistes detailides, mida esimesel pilgul ei oska tähelegi panna. Proosadialoogi mängus pole, aga laul ise on mõnes paikkonnas üles ehitatud dialoogina ja mõnikord esitatudki hobuseotsija ja ühe ringisolija vastastikuse lauluna, millest saab teateid kadunud hobuse kohta. Laulu ajal "hobune" käitub hobusena - hirnub, trambib ja hüpleb, ning hobuseotsijad suksutavad. Nii ei toimu siin tegelaste määratlemine ainult sõna abil, vaid kasutatakse ka etenduslikke võtteid, imiteerides kujutatava looma häälitsust ja liikumist. Setus on nii laul kui ka mäng veidi teistmoodi. Laulu esimene pool on hobuseotsija jutustus, teine pool on küll samuti dialoogikujuline, aga see on hobuseotsija ja hobuse dialoog (tavaliselt on hobune eeslauljaks ka oma repliikide puhul). Nii võib hobune selles mängujärgus olla mõnevõrra antropomorfiseeritud. Antud mängu puhul ei takista see antropomorfne joon mängijat hobusena hirnumast ja hüplemast (mida tehakse eriti laulu esimese poole ajal laulusõnade illustreerimiseks ja tegelase identifitseerimiseks). Setu "Hobusemängus" esineb ka proosadialoogi, aga see on hobuseotsija dialoog teiste mängijatega, kes annavad teateid hobuse kohta. Hobuse kujutaja käitub dialoogi ajal hobusena. Seega võib öelda, et "Hobusemängu" setu redaktsioonis on loomtegelane osaliselt antropomorfiseeritud, üle-eestilises aga täiesti antropomorfiseerimata. Erinevus on veel 
selles, et Setus on hobuseks tüdruk ning hobuseotsijad peavad ise aeda sisse tungima ja hobuse kätte saama. Mäng lõpeb siis kas hobuse kinnivõtmisega (Setus ja üldse Kagu-Eestis) või väljapääsemisega (mujal Eestis), millele võib järgneda hobuse müümine. Leitu või kinnipüütu müümine-ostmine on stereotüüpne mänguosis, mida soovi korral liideti mängude lõppu. Enamasti polnud müümine-ostmine otseselt mängusüžeest tingitud. Nii on hobuse müümine iseenesest nagu improvisatsioon teemale, ilma etteantud kinnisrepliikide või muude pidepunktideta. Ning etendati seda lausa jantlikult. Hobune tegi kõike, mida üks ohjeldamatu, põikpäine ja peru hobune teha võis - hirnus, hüples, rabeles, jooksis eest ära, lõi takka üles, viskas selgaistujad maha. Omanik ja ostjad omakorda püüdsid vaadata hobuse hambaid ja kapju, selga istuda jms. Sõnaga - lasti käiku kõik teadmised, mis taluinimesel hobuse olemusest, käitumisest ja kohtlemisest olid. Sellega seostati aga ka hobuserolli täitjale kui konkreetsele isikule suunatud naljad ja pilge.

Milline on siis vanade laulumängude loomtegelane? Üks võimalik liigitusalus on antropomorfiseerimisaste. Loomtegelase antropomorfsust väljendab ennekõike inimkõne valdamine. See on vastandnähtus loomahäälitsuste matkimisele, mis on peamine kujutamisvõte kui tahetakse esile tuua loomapärasust. Lähtudes antropomorfiseerimisastmest saame järgmised rühmad:

1. Täielikult antropomorfiseeritud loomtegelane. Selline saab olla ainult mängu peategelane, enamasti inimese vastasmängija (hunt "Lambamängus"), kuid peategelastena vastandatud võivad olla ka kaks antropomorfset looma või lindu (kull ja kukk "Kullimängus"). Oma kõnes ja käitumises on loomad küll inimestatud, mängukonflikti aluseks on aga just tegelase loomaolemus. Niisiis võiks antropomorfset loomtegelast kirjeldada nii: inimene mängib looma, kes mängib inimest.

2. Osaliselt antropomorfiseeritud loomtegelane. See võib olla nii kõrvaltegelane (koer "Lambamängus") kui ka peategelane (hobune setu "Hobusemängus"). Rolliloomist iseloomustab üldiselt loomapärane käitumine ja häälitsemine, millele aga lisanduvad mõned inimkõnelised repliigid või lauluosad.

3. Antropomorfiseerimata loomtegelane. See on enamasti kõrvaltegelane (lambad "Lambamängus"), ent vahel ka peategelane (hobune üle-eestilises "Hobusemängus"). Kujutamisvõttestikku aluseks võttes võib antropomorfiseerimata tegelasi omakorda jagada kahte rühma: a) tegelased, kelle puhul imiteeritakse vastava looma häälitsust ja käitumist; b) tegelased, kelle puhul piirdutakse verbaalse teatamisega, missuguse loomaga on tegu, ning keda otseselt ei kujutata ei antropomorfsena ega loomapärasena ( $\mathrm{nn}$ neutraalne tegelane). Viimaseid ei esine etendusmängudes, kus kõik tegelased peavad mingil moel ja määral ümber kehastuma. 
Niisiis võib mängu peategelane olla täielikult või osaliselt antropomorfiseeritud või antropomorfiseerimata, kuid kaht viimast kohtab ainult nõrgema konfliktiga mängudes, kus peategelaste vastandus pole nii terav. Täielikult antropomorfiseerimata saigi peategelane olla vaid sellises mängus, kus tal pole repliike ning tema etenduslik osa on pantomiimiline. Antropomorfiseerimise vastandnähtuseks on siis looma natuurilähedane imiteerimine. Loomapärasuse etendamise vaatlusel võibki kõrvale jätta nii antropomorfse loomtegelase (keda iseloomustab inimese kõne ja käitumine) kui ka nn neutraalse tegelase. Mõlemal puhul saame peamiselt verbaalselt, ennekõike sissejuhatava lauluteksti kaudu teada, et tegu on loomadega. Loomapärasuse väljamängimisel, nagu eespoolgi öeldud, on esmane võte vastava loomaliigi häälitsuse matkimine. See eraldab tegelase selgelt nii teistest loomaliikidest kui ka inimestest. Süvenenuma ümberkehastuse puhul lisanduvad looma liikumise ja käitumise jäljendamine. See ulatus küll harva niikaugele, et nõuti ebamugavat neljakäpakil käimist (käpuli jooksmist esines kõige sagedamini koera rolli puhul mängudes, kus ta oli episoodiline kõrvaltegelane). Kõrget meisterlikkust nõudis hobuse pantomiimiline roll juhul, kui etendati ka hobuse müümist. Kõik kasutatavad võtted on väga tabavad, tüüpilised ja sealjuures omamoodi primitiivsed. Nad kuuluvad konkreetse, natuurilähedase imitatsiooni tasandile, mis põhineb otseselt meelte andmetel. Loomulikult eeldas see vastava looma head tundmist, kuid eks need mängud tekkisid ja elasidki talupojakeskkonnas.

Mingil määral on vanemates laulumängudes ka abstraktsema tasandi imitatsioonivõtteid, kujutamist mingi tingmärgi, sümboli abil. Selline imitatsioon põhineb sarnasusassotsiatsioonil. Markantseks näiteks on kepi kasutamine hobusena, s.t eseme ümberkehastamine elusaks olendiks. Eespool on öeldud, et laulumängudes kasutati rekvisiite väga harva. Ometi on üks, lausa universaalne rekvisiit - kepp. Kepi metamorfoose demonstreerib hästi "Kosjamäng": kosilane ratsutab kohale hobusel, s.o kepil; talu lähedal tungivad talle kallale koerad - ja silmapilk muutub "hobune" tavaliseks kepiks, et koeri eemale peletada; siis taas hobuseks, et kujuteldava majani jõuda, ning lõpuks uuesti kepiks - vanale kosilasele toeks, rikkale saksikuks uhkuseasjaks. Kepp on alati käepärast ja võimaldab kujutada nii esemeid (nt hundi supikulp ja vikat "Lambamängus") kui olendeidki. Kepphobuse on võimeline välja mõtlema iga laps, kel üldse on aimu hobusest ja ratsutamisest. Nii on selle sarnasusassotsiatsiooni tekkemehhanism kergesti tabatav.

Tuleb tõdeda, et nii esimese kui teise tasandi imitatsioonis toodi esile ainult mõni eriti ilmekas joon, üksikdetail; muu tuli juurde mõelda, oma fantaasia abil täiendada. Laulumängude kujutamislaad on küllalt tinglik, sealjuures aga lähedane lastepärasele piirideta fantaasiale, kus pole hirmu illusiooni rikkuda. See on omapärane natuurilähedaselt realistliku ja assotsiatiiv-tingliku kujutuslaadi 
segu, kus kõik võib tähendada kõike. Sealjuures kasvab kunstiline kujutamine mingite kohe märgatavate, sageli küllalt välistel teguritel põhinevate sarnasus-assotsiatsioonide abil välja reaalelu eeskujudest. Eelöeldu juures tuleb aga meeles pidada, et tegu oli täiskasvanute mängudega ning kirjeldatud loomade mängulise kujutamise viisid pakkusid neile huvi. Kõnealused mängud olid väga populaarsed. Muidugi tuleb siin arvestada teisigi tegureid (et mängud võimaldasid noortele omavahelist suhtlemist, et nad haarasid kaasa kogu pere jms). Need aspektid on olulised selgitamaks mängude erakordset populaarsust, kuid ei liitu kuidagi loomtegelaste osatähtsusega neis. Et loomade mänguline kujutamine oli täiskavanutele huvitav, tulenes ilmselt looduslähedasest elulaadist ning sellega kaasnenud maailmakäsitusest ja uskumuslikest tõekspidamistest, mis kõik moodustasid ühtse terviku.

\section{Loomtegelased siirdevormilise lauluga mängudes}

Laulumängude järgmist selgemini piiritletavat kihistust iseloomustab liikumise suurem tantsulisus. Laulud ei esinda enam puhast regivärsistiili, vaid on siirdevormilised, sisaldades märke uuemast laulustiilist (värsside ja poolvärsside kordamisel kujunevad stroofistruktuurid, lõppriimialged, spetsiaalviisid jms). Enamasti saadab laul kogu mängutegevust. Laulumängude üldarengule ongi iseloomulik, et laul ja tegevus seostuvad omavahel üha enam. Veel hilisemates ringmängudes on laul ja tegevus, olgu see siis tantsuline või dramaatiline, absoluutselt seotud ja kogu mäng toimub laulu saatel. Vanemates laulumängudes on üksikosad suhteliselt iseseisvad: mõne komponendi võib eraldada ja ikkagi jääb järele huvipakkuv mäng. Selline vaba osa oli ekspositsioonlaul, mis mängude hilisemas arengujärgus - regivärsilise rahvalaulu hääbumise ajal lihtsalt ära jäi. Näiteks algsed laulumängud "Lambamäng” ja "Kullimäng" olid veel eelmisel sajandil käibel lauluta lastemängudena.

Muutusid ka mängude teemad, keskseks tõusid kosjamotiivid, noorte vastastikused sümpaatia-avaldused. Ainuvaldava talumiljöö kõrvale asus linn oma elanikega ning isegi aadliseltskond, tsunftitegelased, rändavad moosekandid, lossiemandad. Nende mängude laenulisus on ilmne. Suur osa neist pärineb hiliskeskaegsetest Euroopa kultuuritsentrumidest ning meile on nad jõudnud peamiselt Rootsi, Soome ja Saksamaa kaudu. Siin on nad (eriti varasemad laenud) omandanud teatud määral talupoegliku rüü, jooni kohalikust olustikust, nagu see on omane ka samasugusele internatsionaalsele muinasjutužanrile. Taluolustikust eemaldumine tõi loomulikult kaasa eemaldumise loodusest ja loomadest. Teatud tõenäosusega võib siit järeldada, et oli tekkinud mingi nihe talupoja loodustunnetuses üldse, mis kajastus ka kunstilise kujutamise vor- 
mides, kaasa arvatud mängud. Uue moe vastuvõtmisel on ju alati ka mingid sügavamad juured.

Sellesse kihistusse kuuluvatest mängudest on üks vanemaid "Midrilinnumäng" (vt Rüütel 1980: 171-187), mis oli Rootsis hästi tuntud 17. sajandil ja jõudis samal ajal siiagi. Üldvormilt sarnaneb mäng nii varasemate sõõr- kui ka hilisemate ringmängudega: osavõtjad käivad ringis ja laulavad. Ringi (“aia”) sees on lind, väljaspool kütt (mõnikord koos koeraga). Kõige levinuma mänguviisi järgi tõstavad ringis seisjad laulu lõppedes käed üles (kätest moodustatud väravad on iseloomulik detail selle rühma mängudes) ning kütt hakkab lindu taga ajama. Joostakse ringist sisse ja välja, ringis seisjad kumbagi ei takista. Mängu hilisemas arengujärgus asendub jooks tantsuga. Sellise mängutegevuse juures on peaaegu ükskõik, kuidas tegelasi nimetada, dramaatilist kujutamist ju ei toimu, see on lihtsalt liikumismäng laulu saatel. Mõnede teisendite põhjal on aga laulus jutustatavat sündmustikku mingil määral etendatud. Laulu viimaste sõnade juures ("lase püss, kui oskad, peale") peab kütt lindu millegagi viskama (tavaliselt nutsakusse keeratud rätikuga). Kui ta pihta saab, määratakse uued tegelased. Või siis ütleb kütt lihtsalt “põmm!”, lind jookseb ringist välja ning kütt ja koer peavad teda püüdma. On esinenud isegi lindu iseloomustavaid imitatsioonivõtteid: laulu ajal lind hüpleb ja nokib (nokkimist edastas mängupärane tingvõte - linnurolli täitja näppis sõrmedega ringis olijaid). Sellise mänguviisi puhul pole põhimõttelist struktuurierinevust võrreldes mõnevõrra vanema "Hobusemänguga" (mille kõik lauluredaktsioonid esindavad regivärsistiili): mängijad liiguvad sõõris ja laulavad; laul on põhitegevusele ekspositsiooniks, lauluga kaasneb imiteeriv tegevus; lõpplahenduseks on sportlik tegevus. Ka "Midrilinnumängu" laulu varasemad variandid on vormilt küllaltki regivärsilähedased. Oluline erinevus vanadest mängudest väljendub laulutekstis ja nimelt teema ja tegelaste valikus. Peategelaseks on imepärane midrilind, tegevuspaigaks aga mõisaaed, kus kasvavad erilised taimed - petersellid, piprajuured jms, niisiis mitte enam reaalsed talulinnud ja tavaline taluõu. Tegevuses on märgatav tantsu- ja spordielementide domineerimine draamaelementide üle (hilisemates variantides ei esine viimaseid peaaegu üldse) ning mõningane teisenemine dramaatilise kujutamise võttestikus. Laulusõnades esinevale ilutsemisele vastab illustratiivsus tegevuses. Tegelikkuse tõemeelse, võimalikult loomutruu jäljendamise asemel on rohkem mänglevaid tingvõtteid.

Toimunud muutused on selgemini märgatavad mängudes, kus on tegu kasvav-kahanevate viirgude vastamisi liikumise või kasvav-kahanevas vooris liikumisega. Viimasega kaasneb enamasti kätest moodustatud väravatest läbikäimine (mis võib lisanduda ka sõorrmängudele nagu eeltoodud "Midrilinnumäng"). Kõik need võtted on mängulised paralleelid omaaegsetele seltskonnatantsudele. Sellesse mänguderühma kuulub E. Enäjärvi-Haavio poolt monograafiliselt 
käsitletud "Rikka ja vaese mäng", millest Eestis teatakse kuut redaktsiooni (Enäjärvi-Haavio 1932: 171-187). Kahes neist on tegelasteks linnud: ühes rikas ja vaene lind; teises rikas mees, kel palju linde ja vaene mees, kel pole ühtegi. Mängutegevuses on põhiline abstraktne tantsulis-figuraalne liikumine: rikka (linnu) järel vooris on palju poegi, vaene on üksi, teatud lauluosa järel läheb üks mängijatest üle vaese poole ja lõpuks osad vahetuvad - vaesest on saanud rikas. Laul saadab siin tegevust kogu aja. Konflikti ajend - eetilis-sotsiaalne rikkuse ja vaesuse vastandus - on puhtalt inimühiskonnale omane (vanas regivärsilises "Kullimängus", mis on vormilt samuti voormäng, pärines konflikti ajend loodusest). Selliste probleemide tulek mängudesse kajastab kindlasti mitte ainult mängude moemuutusi, vaid mingil määral ka muutusi ühiskonnasuhetes üldse ja nihkeid talupoja maailmanägemises. "Rikka ja vaese mängus" on tõepoolest üsna ükskõik kuidas tegelasi nimetada - kas mees, lind või puu. Et tegelasteks on linnud, see selgub ainult laulusõnadest, s.o verbaalselt. Lindtegelased on lihtsalt kooskõlas selle mänguderühma lauludele üldisemalt omase ilutseva laadiga. Etenduslikult ei püüta tegelasi kujutada lindudena, vaid hoopis rikkana ja vaesena. Nimelt liigub rikas (lind) uhkelt, rind ees ja pea püsti, laulab võimuka häälega; vaene seevastu liigub jalgu liibates, noruspäi ja laulab hädise häälega. Niisiis esitatakse teatud sotsiaalse karakteristikaga tegelasi mingite kindlate, tüüpi iseloomustavate võtetega. Siin ei ole ka tegelaste antropomorfiseerimist selles mõttes, nagu see esines "Kullimängus", kuna neid ei tunneteta üldse loomariiki kuuluvatena. Neid võiks tähistada terminiga formaalne loomtegelane. Kogu tegevus toimub laulu ajal ning on seetõttu oma olemuselt illustratiivne, ainult ilmestab teksti. Sealjuures on laul aga üles ehitatud dialoogina - rikkad ja vaesed laulavad vastamisi. Nii on "Rikka ja vaese mäng" küll väheste draamaelementidega laulumäng, kuid loomtegelase osa siin, nagu öeldud, on formaalne.

Samasse mängudekihistusse kuulub ka "Hanemäng", kus on teksti põhjal tegelasteks haned ja luiged. Nendevahelist konflikti võiks jälle nimetada eetiliseks (inimühiskonnale omaseks, mitte looduslikest vahekordadest lähtuvaks) - haned on pesnud oma pojad ja jätnud luigepojad pesemata. Karistuseks takistatakse voorina liikuvaid hanesid kahe luige moodustatud väravast läbi pääsemast ja viimane mängija jääb väravasse kinni. Tegevus toimub laulu ajal, proosadialoogi mängus pole. Sündmustikku ei etendata draamavõtetega, vaid selle kujutamine on üle kantud abstraktsemasse tantsukeelde, tantsulisfiguraalsesse liikumisse. Laulmine toimub jällegi laulusõnades vastandatud tegelaste dialoogina. Vastandatus ilmneb samuti tegelaste paiknemises, nagu see oli põhiasendiks ka vanades voormängudes (nt "Kullimäng"). Mõnede kirjapanekute põhjal on "Hanemängus" tehtud linnu tiibade liikumist imiteerivaid käteliigutusi. Tasub tähele panna, et linnupärasust väljendatakse siin rütmi- 
liste liigutuste abil, mis omakorda tähistab lähenemist tantsule (vanas voorivormiga "Kullimängus" imitatsioon-tantsude võtteid ei kasutatud). Kahtlemata on ka "Hanemängu" puhul tegu draama- ja tantsuelementidega laulumänguga, kuid vanade voormängudega võrreldes on tantsuelementide osakaal siin tunduvalt suurem. Kuna konflikt ei lähtu tegelikust vastuolust looduses, siis ei saa rääkida ka tegelaste antropomorfiseerimisest, nagu see toimus "Kullimängus".

Niisiis võib selle rühma mängude juures lisaks üldisematele struktuurimuutustele (laul saadab enamasti kogu mängu, proosadialoogi, üldse proosarepliike esineb harva, tantsuelemendid domineerivad draamaelementide üle jms) täheldada muutusi ka loomtegelaste osalemises ja kujutamises.

1. Loomtegelaste kaudu lahendatakse probleeme, mis on ainuomased inimeste keskkonnale, konflikti aluseks pole enam looduslikest vahekordadest lähtuv vastuolu. See toob mängudesse nn formaalse loomtegelase. Et tegu on loomaga (resp linnuga), saame teada ainult verbaalselt, mänguliste võtetega ei püüta tegelast loomana kujutada. Kuna konflikt ei lähtu tegelase loomaolemusest, ei saa nende mängude puhul rääkida ka antropomorfiseerimisest. Antropomorfne loomtegelane selles tähenduses, nagu ta esineb vanades mängudes, siin puudub.

2. Kuna paljudes mängudes toimub tegevus ainult laulu ajal, tuleb uue joonena sisse loomtegelaste kujutamine tantsuvõtetega, rütmiliste liigutuste abil. Selline lähenemine imitatsioontantsudele pole siiski kuigi üldine.

3. Tegevuse suurem sõltuvus laulust ning muutumine lauluteksti illustratsiooniks toob kaasa teisigi nihkeid loomtegelaste kujutamisel. Nimelt pole imiteerimisel enam esmaseks võtteks häälitsuste matkimine, vaid liigutuste ja tegevuse matkimine. Seegi ei toimu enamasti reaalse eeskuju otsese ülekandena, vaid mingi, juba teatud määral abstraheerunud tingmärgi abil.

Tuleb märkida, et loomariigi esindajateks neis mängudes on sagedamini linnud. See on kaasnähtus sentimentaalsele ja ilutsevale laadile, mis hakkab ilmnema juba selle kihistuse mängudes.

\section{Loomtegelased ringmängudes}

Laulumängude kõige hilisemaks kihistuseks on lõppriimiliste laulude saatel mängitavad ringmängud, mis pääsesid võidule 19. sajandi keskpaiku seoses paaristantsu (polka, labajalavalss, valss jt) levikuga. Ometi tõid ringmängud kaasa uue dramatismilaine. Nimelt on üsna paljudes ringmängudes algul esinenud draamaelemente, mis hiljem on taandunud paaristantsu ees. Kuid ka 
draamaelementidega ringmängudele on iseloomulik, et tegevus toimub laulu ajal ja illustreerib teksti - vastupidi vanematele laulumängudele, kus laul on enamasti ekspositsiooniks, aga intriigi arendav tegevus toimub pärast laulu ja on sageli seotud proosadialoogiga. Ringmängudes proosadialoog puudub. Tegevus on laulust sõltuv ja seega äärmiselt napp, otsekui stiliseeritud, koosnedes üksikutest tingvõtetest. Need on mõnesugused kokkuleppelised, teatud kindlaid emotsioone ja tegevusi väljendavad žestid ja miimika ning tegelaste lahkumisi ja naasmisi sümboliseerivad ringist sisse ja välja käimised.

Ringmäng kui mänguvorm muutus kiiresti väga populaarseks ning seostus paljude lauludega, millel varem mängu saatefunktsioon puudus. Isegi mõnedest regivärsilistest lauludest kujunesid uued, ringmängulised versioonid. Üks selliseid, kus esinevad ka loomtegelased, on "Siidisulgis linnuke". See on ürgvanast, läänemeresoome ühislauluvarasse kuuluvast "Loomislaulust" 19. sajandi keskel tõenäoliselt Mulgimaal kujunenud siirdevormiline lauluversioon, millele on liitunud mängufunktsioon (vt Rüütel 1969: 102-132; Rüütel 1980: 284-288). Osavõtjad liiguvad ringis, üks, keda laulus nimetatakse "siidisulgis linnukeseks", on keskel. See lendab algul "kullast põõsa peale" (s.t paneb käed kellegi ringis olija kaela ümber), siis "hõbepõõsa peale" (kelleks on teine ringis olija) ning siis "siidist põõsa peale" (kolmas ringis olija). "Siidipõõsa" tõmbab ta ringi sisse. Laulusõnade järgi hakkab lind nüüd pesa tegema. Tegevusega kujutatakse seda nii: lind näpib ringis olijaid, nagu korjaks pesamaterjali. Siis võtab ta ühe mängija sisse "pesaks". Edasi võtab ta ringis käijate hulgast sisse algul ühe, siis teise ja kolmanda poja. Need hüplevad nagu linnupojad. Kaks poegadest, kes on "kurja kulli seltsi", viskab ta vastavate laulusõnade ajal ringist välja ning lahkub isegi. Sisse jääb lõpuks ainult üks poegadest uus "siidisulgis linnuke". Lindu kujutatakse siin tõepoolest linnuna, selleks kasutatavad võtted on aga küllalt tinglikud (kaasmängijate näppimine pesamaterjali korjamise tähisena, mängijate sissetõmbamine ja väljalükkamine jms). Natuurilähedasem imitatsioon (karglevad linnupojad) jääb siin väheoluliseks detailiks. Üldiselt on loomarollid draamaelementidega ringmängudes harv nähtus. Õieti on "Siidisulgis linnuke" üks väheseid, mis tervikuna kujutab elu looduses, kuid see kujutlus ei ole kuigivõrd kooskõlas tegeliku olukorraga. Näiliselt pärineb konflikt küll loodusest, kuid selle taustaks on inimlik hea ja kurja vastandus. Enamasti kajastataksegi draamaelementidega ringmängudes loomtegelaste kaudu lausa inimeste elu (nt paarilise valimisega mäng "Kaks midrilindu roosiaias").

Niisiis süvenevad ringmängudes mõned jooned, mis said alguse juba eelmises mänguderühmas. Need on suurelt osalt tingitud põhilisest struktuurimuutusest, s.o laulu ja tegevuse samaaegsusest, mistõttu tegevus on ainult laulusõnade illustratsiooniks. Selgelt ilmneb nüüd üldisemat mentaliteedimuutust kajastav 
sentimentaalne tundetoon. Imitatsioonivõtetega kujutatavad loomariigi esindajad on nüüdki peamiselt linnud. Jäljendatakse justnagu nende looduslikku elu ja olemust, kuid seda tehakse eeskujukaugelt, ilutseva mänglevusega.

\section{Kokkuvõtteks}

Kokkuvõtteks tuleb rõhutada, et eelvaadeldud mängud olid kõik täiskasvanute omad, kuigi teatud situatsioonides võisid neid (kas koos "suurtega" või omaette) mängida ka lapsed. Täiskasvanute jaoks tähenduse kaotanud, ongi osa neist pudenenud lasterepertuaari. Laulumängud olid meie talupojakeskkonnas põhilisi ajaviite- ja lõbustusvorme 19. sajandi lõpuni ja küllalt olulised veel eelmise sajandi esimestel kümnenditel. Siin on olnud juttu kolmest selgemini piiritletavast kihistusest, kuid nendegi dateerimine on paratamatult umbkaudne. Ajaliselt lähedasemad, kus leidub palju võrdlusmaterjali teistelt rahvastelt ning ilmnevad uued jooned laulustiilis ja mängustruktuuris, on muidugi ligikaudselt paikapandavad. Sellised on alates 16. sajandist siia tulvanud tantsulis-figuraalsed, väheste draamaelementidega mängud ning 19. sajandi keskpaiku, rahvalaulu suhtes murranguliste aegadega kaasnenud ja juba lõppriimilisele laulule ehitunud ringmängud. Aegade hämarusse kaob aga regivärsiliste, draamalaadsete laulumängude teke (esimene juhuslik kirjalik registreering pärineb aastast 1680), kuid nende seos vanade rituaalidega ning animismist juurduva maailmakäsitusega on väljaspool kahtlust. Võttes laulustiili aluseks, jagamegi laulumängud vanemateks, regivärsilise lauluga ning uuemateks, siirdevormilise ja lõppriimilise lauluga mängudeks. Uuem laulustiil tungis aga mängulauludesse küllalt vara, nähtavasti juba 16. sajandil, ning pikka aega eksisteerisid mõlemad stiilid kõrvu just mängulaulude näol. Kui Setumaa eriolukorda arvestada, kus regivärsiline rahvalaul on mingil moel elus veel tänapäeval, võib öelda, et ka vanad laulumängud on püsinud meie päevini. Aga mujaltki kui Setust on olnud võimalik vanu laulumänge lähiajal kirja panna. Kuusalu rannakülades, kus samuti palju harrastati laulumänge, oli traditsioonilises mõttes häid laulikuid veel eelmise sajandi algupoolel, ning nende lapsed mäletasid laulumänge veel 1960. ja 1970. aastatel. Ka Mulgimaal on olnud laulumängude hilisõitseng. Kindlasti on mängufunktsioon ühe tegurina aidanud regilaulul säilida. Mängudel omakorda on aidanud säilida tavade püsivus (nt jõulumängude komme).

Iga mängukihistus, mis mingil määral ju kajastab üldisi moe- ja mentaliteedimuutusi, on kaasa toonud omad vormid, kujutuslaadi ja -võttestiku. Midagi sellest ilmneb ka loomtegelaste mängudes osalemises ja nende mängulises kujutamises. Draamalaadsed laulumängud, mis peegeldavad talupoegade 
looduslähedast elu ning on juurtega kinni vanades uskumustes, ilmutavad hoopis teistsugust loodussuhet kui uuemad. See väljendub ühelt poolt loomtegelaste antropomorfiseerimises, nende võrdsustumises inimesega, teiselt poolt aga looma natuurilähedases jäljendamises. Imitatsioonivõtetest kõige üldisem on looma häälitsuse matkimine, mis selgelt eraldab ühe liigi teisest ning on vastandnähtuseks inimkõne valdamisele antropomorfiseerimise puhul. Konflikti ajend neis mängudes pärineb loodusest, ning isegi siis, kui loomtegelane räägib ja tegutseb inimesena, põhjustavad konflikti tema loomainstinktid ja -karakter. Sageli vastanduvad kodu ja mets. Koos sellega peegelduvad mängudes maagilised toimingud, mida võeti ette koduloomade kaitsmiseks metsloomade eest.

Järgmistes, tantsulis-figuraalsetes, väheste draamaelementidega laulumängudes, ilmneb põhimõtteliselt teistsugune lähenemine - loomtegelase kaudu kajastuvad inimkonnale ainuomased eetilis-sotsiaalsed probleemid, mitte looduslik olelusvõitlus. Niisiis mitte inimese ja looma või looma ja looma, vaid inimese ja inimese vahelised suhted. Kuna siin ei saa rääkida antropomorfiseerimisest (mille eelduseks on antud käsitluses loomtegelase loomaomadustest lähtuv konflikt), tuleb loomtegelase osa sellistes mängudes pidada puhtformaalseks. Kõnealuses rühmas esineb küll ka mänge, kus loomtegelase esitamiseks on kasutatud imitatsioonivõtteid, kuid enamasti on need abstraktsemad, reaalsest eeskujust kaugenenud tingvõtted või koguni tantsuvõtted, rütmistatud liigutused. Looma või linnu kujutamisel ongi nüüd kõige põhilisem võte liigutuste ja liikumise jäljendamine, mis muidugi on kooskõlas nende mängude tantsulisema karakteriga.

Kolmandas kihistuses, draamaelementidega ringmängudes, tulevad selgelt esile juba eelmises rühmas märgatavad jooned, eeskätt sentimentaalne meeleolutsemine, mis on üks juhtivaid tundetoone uuemas rahvalaulus. See kandub üle ka tegevusele. Kuigi siin mõne mängu puhul domineerivad draamaelemendid tantsuelementide üle (nagu vanemates laulumängudest), on loomade eeskujulähedase imiteermise asemel neid kujutatud mõnesuguste, oma olemuselt palju abstraktsemate ja üldistatumate tingvõtetega. Üldisest laadist ja tundetoonist rääkides võiks öelda, et tõsimeelse mängu ja tegelase kujutamise asemele on astunud ilutsev mänglemine ja tegelase kujundamine. Nii on kujutamislaad rahvamängudes sügavas kooskõlas oma ajastu muude kunstinähtustega ning kajastab üldisemaid moe- ja mentaliteedimuutusi.

\section{Kommentaar}

1 Artikkel on esmakordselt ilmunud 1998. aastal väljaandes "Emakeele Seltsi aastaraamat 35-42, 1989-1996" (toimetaja Tõnu Tender), lk 67-85. Tartu: Eesti Teaduste Akadeemia Emakeele Selts. 


\section{Kirjandus}

Ariste, Paul 1927. Setu jõulumängudest. Album M. J. Eiseni 70. sünnipäevaks. Tartu: Eesti Kirjanduse Selts, lk 121-133.

Bogatõrjov, Pjotr 1970 = P. G. Bogatyrev. Zametki o narodnom teatre. Acta Ethnographica Academiae Scientiarum Hungaricae 19, lk 53-64.

Enäjärvi-Haavio, Elsa 1928. Nukke. Kalevalaseuran vuosikirja 8, lk 259-263.

Enäjärvi-Haavio, Elsa 1932. The Game of Rich and Poor. A Comparative Study in Traditional Singing Games. Helsinki: Suomalainen Tiedeakatemia.

Enäjärvi-Haavio, Elsa 1936. Über nordische Kinderspiele. Haavio, Martti \& Penttilä, Aarni (toim). Studia Fennica 11 (3). Helsinki: Suomalaisen kirjallisuuden seura, lk 99-127.

Häyhä, Johannes 1982. Vuodenajat. Kuvaelmia itäsuomalaisten vanhoista tavoista. Jõulun vietto, talvitoimet, kesäaskareet. Helsinki: SKS.

Jürgenstein, Anton 1909. Eesti vanad mängud. Eesti Kirjandus 11, lk 417-428; 12, lk 461-465.

Kuusi, Matti 1963. Esisuomalainen runous. Konsala, Simo \& Kuusi, Matti (toim). Suomen kirjallisuus I. Kirjoittamaton kirjallisuus. Helsinki: Suomalaisen kirjallisuuden seura, lk 31-80.

Mirov, Ruth 1974. Vanemate laulumängude struktuuritüüpidest. ENSVTA Toimetised. Ühiskonnateadused 2, lk 179-186.

Mirov, Ruth 1976. Draamaelementidest vanemates laulumängudes. "Lambamängu" analüüs. ENSV TA Toimetised. Ühiskonnateadused 1, lk 29-42; 2, lk 165-177.

Põldmäe, Rudolf 1938. Rahvakultuurist, eriti rahva lõbutsemisvormidest Setumaal. Eesti Noorus 4, lk 142-143.

Raussi, Eljas 1966. Virolahden kansanelämää 1840-luvulla. Helsinki: SKS.

Ruuttu, Maija 1926. Kivennapalaisia joululeikkejä. Virittäjä 30, lk 86-91.

Rüütel, Ingrid 1969. Muistne "Loomislaul" eesti uuemas rahvatraditsioonis. Kahu, Meelik (toim). Paar sammukest eesti kirjanduse uurimise teed. Uurimusi ja materjale VI. Tallinn: Eesti Raamat, lk 102-132.

Rüütel, Ingrid 1980. Eesti uuemad laulumängud I. Tallinn: Eesti Raamat.

Tampere, Herbert 1958. Eesti rahvalaule viisidega III. Tallinn: Eesti Riiklik Kirjastus.

Tedre, Ülo 1983. Sünkretism rahvaluules. Keel ja Kirjandus 7, lk 337-340.

Vesselovski, Aleksandr 1940 = A. N. Vesselovskii. Istoricheskaja poetika. Leningrad: Khudozhestvennaia literatura.

Vilberg, Gustav 1920. Jõulumängud. Eesti Kirjandus nr 1/2, lk 45-56; nr 3/4, lk 80-96; nr 5, lk 152-161. 


\title{
Summary
}

\section{Depiction of animal characters in song-games}

\author{
Ruth Mirov \\ folklorist \\ ruthmirov@hot.ee
}

Keywords: animal characters, circle dance, couple dance, dance-figurative games, folklore, line games, performative games, round dance, song-games

The article compares song-games with animal characters in three temporally consecutive song-game layers in terms of their depiction style and game techniques. These are performative games to the accompaniment of runo songs, dance-figurative games to the accompaniment of transitional songs, and insert dance songs to the accompaniment of end-rhyme songs.

For the most part, the animal character of older games is anthropomorphised, has a command of human speech and human activities. Unanthropomorphised animal characters are depicted on the basis of natural examples, by means of distinctive sounds and movements. The conflict in the game also proceeds from the animal characteristics of the characters.

The games in the next layer depict animals as more abstract, and close-to-nature depiction is replaced by consensual symbols and terpsichorean moves. Conflict is a result of ethical-social problems inherent in humans.

The last, round dance layer features, to a small extent, imitation by means of symbols, yet the main activity is (couple) dance to the accompaniment of songs.

The temporal development of song-games moves from the scenes imitating real situations towards more abstract, terpsichorean techniques.

Changes in the depiction of animals and birds in song-games probably reflect general changes in people's perception of nature and receding from it.

Ruth Mirov on eesti rahvaluuleteadlane, kelle põhilised uurimisalad on olnud eesti regivärsiline rahvalaul, vanemad laulumängud ja rahvaluule kasutamine kirjanduses. Ta on avaldanud olulisi käsitlusi August Annisti ja Betti Alveri loomingust, kirjutanud ka luulekriitikat.

Ruth Mirov is Estonian folklorist, whose main research areas have involved Estonian runo song, older song-games, and the use of folklore in literature. She has published significant treatments of August Annist's and Betti Alver's oeuvre as well as poetry criticism.

ruthmirov@hot.ee 